\title{
Optimization of Medium Composition for the Mycelial Growth of Sparassis crispa
}

Jin-Woo Kim', Woo-Jae Cheon', Kyung-Hee Chai', Dong-Gwan Kim², Sung-Ho Son ${ }^{2,3}$, Jong-Guk $\mathrm{Kim}^{4}$ and Hee-Jae Lim* ${ }^{1}$

${ }^{1}$ Gyeongsangbuk-Do Forest and Environment Research Institute, Gyeongiu 780-936, Korea

${ }^{2}$ Institute of Biotechnology, Vitrosys Incoporation, Yeongiu 750-804, Korea

${ }^{3}$ Department of Biochemical Engineering, Dongyang University, Yeongiu 750-711, Korea

${ }^{4}$ School of Life Science and Biotechnology, Kyungpook National University, Daegu 702-701, Korea.

Received December 5, 2011 /Revised December 26, 2011 /Accepted December 29, 2011

The characteristics of mycelium growth of Sparassis crispa KGFS08 and KFRI746 in liquid culture were investigated. The optimum growth of the mycelium of $S$. crispa was observed in the KTM medium. The best carbon source was starch. In terms of nitrogen sources, tryptone affected mycelial growth in the liquid culture. The optimal culture conditions were $\mathrm{pH} 4.0-5.0$ in STK medium [3\% (w/v) starch, $0.3 \%(\mathrm{w} / \mathrm{v})$ tryptone, $0.1 \%(\mathrm{w} / \mathrm{v}) \mathrm{KH}_{2} \mathrm{PO}_{4}$, and $0.1 \%(\mathrm{w} / \mathrm{v})$ folic acid].

Key words : Sparassis crispa, mycelial growth, liquid culture, carbon source, nitrogen source

서 론

꽃송이버섯(Sparassis crispa Wulf.: Fr.)은 균계(Fungi), 담자 균문(Basidiomycota), 담자균강(Basidiomycetes), 주름버섯아 강(Agaricomycetidae), 구멍장이버섯목(Polyporales), 꽃송이 버섯과(Sarassidaceae), 꽃송이버섯속(Sparassis)에 속하고 있 다[6]. 우리나라의 꽃송이버섯은 소나무, 잣나무, 낙엽송, 전나 무 등 침엽수에 발생하고 5월부터 발생하기 시작하여 여름철 (7 8월)에 많이 발견되고 9월까지 발생한다고 알려져 있다[8]. 꽃송이버섯은 $\beta-1,3$-glucan 함량이 높아 세포 면역기능이 향 상되어 항암활성이 뛰어난 것으로 나타나 있어 그 효능은 이 미 입증된바 있다 $[4,9,13]$. 꽃송이버섯은 식·약용이 가능한 버 섯으로써 최근 인공 재배까지 가능하게 되어 건강기능성 식품 및 의약품 소재로써 가능성이 매우 높다. 하지만 자연 상태의 꽃송이버섯은 발견하기 힘들고 인공 재배의 경우에도 평균 70 80일 배양 기간과 35 45일 자실체 생육 기간이 소요된다 [10,11]. 이와 같은 장기간 배양으로 인하여 안정적인 재배법이 확립되지 않고 있다. 이러한 문제의 해결을 위해서는 우선적 으로 액체 종균 배양에서부터 생리적, 화학적 특성 규명이 필 요하다. 따라서, 본 연구에서는 균사가 필요로 하는 탄소원·질 소원 종류 및 농도, $\mathrm{pH}$, 배양 기간 등을 조사하고 대량 생산을 위한 접종원의 형태로써 액체 종균이 적합하므로 꽃송이버섯 의 균사 액체 배양 특성 조사를 통하여 꽃송이버섯의 균사 생리 특성을 규명하여 꽃송이버섯 대량 재배 및 균사체 산업 화에 응용하고자 한다.

\footnotetext{
${ }^{*}$ Corresponding author Tel : +82-54-778-3833, Fax : +82-54-778-3840 E-mail : bigtrees@korea.kr
}

\section{재료 및 방법}

\section{공시 균주}

본 시험에 사용한 균주는 경상북도산림환경연구원이 보유 하고 있는 KGFS01 등 8종과 국립산림과학원이 보유하고 있는 KFRI644 등 10종을 분양 받아 사용하였다(Table 1). 균주는 PDA (potato dextrose agar, Difco 사) 배지에서 배양하여 $4^{\circ} \mathrm{C}$ 에서 보존하고, 8 주마다 계대 배양한 것을 $25^{\circ} \mathrm{C}$ 에서 배양하면 서 실험에 사용하였다.

\section{분자생물학적 동정}

본 연구에 사용된 경상북도산림환경연구원 균주 KGFS01 등 8 종의 균주에 대하여 분자생물학적 동정을 위하여 internal transcribed spacer 1, 5.8S ribosomal RNA gene, internal transcribed spacer 2 (이하 ITS1-5.8S rRNA-ITS2) 영역의 염기서열 을 분석하였다. PDB (potato dextrose broth) 배지에서 정치 배양하여 수거된 균사체는 액화질소에 넣고 분쇄하여 total $\mathrm{DNA}$ 를 추출 하였다. 추출한 DNA 증폭은 Takara 사의 'Takara PCR Thermal Cycler DICE'를 사용하고 중합효소는 Solgent 사의 'EF Taq DNA polymerase'를 사용하였다. PCR 반응 조건은 $95^{\circ} \mathrm{C}\left(20\right.$ 초), $58^{\circ} \mathrm{C}\left(40\right.$ 초), $72^{\circ} \mathrm{C}$ (1분)으로 30 회 반 복하였다. 프라이머는 ITS1 primer (5'-TCC GTA GGT GAA CCT GCG G-3')와 ITS4 primer (5'-TCC TCC GCT TAT TGA TAT GC-3')을 Jenotech 사에 의뢰하여 제작하였다. PCR 결과 물은 Promega 사의 'pGEM easy T-vector'를 사용하여 재조합 하였고, 재조합 T-vector는 RBC (Real Biotech Corp.) 사의 'HIT-DH5a' competent cell에 형질전환 하였다. 형질전환이 확인된 재조합 T-vector는 Solgent 사에 의뢰하여 삽입 부위인 ITS1-5.8S rRNA-ITS2 염기서열을 분석하였다. 
Table 1. The list of Sparassis crispa strains used in this study

\begin{tabular}{|c|c|c|c|}
\hline Strain & Source & Year & Present \\
\hline KGFS $^{\text {a) }} 01$ & Chilgok & 2008 & 0 \\
\hline KGFS02 & Chilgok & 2008 & 0 \\
\hline KGFS03 & Chilgok & 2008 & 0 \\
\hline KGFS04 & Chilgok & 2008 & 0 \\
\hline KGFS05 & Chilgok & 2008 & O \\
\hline KGFS06 & Chilgok & 2008 & 0 \\
\hline KGFS07 & Chilgok & 2008 & 0 \\
\hline KGFS08 & Chilgok & 2008 & 0 \\
\hline KFRI $^{\mathrm{b})} 644$ & Gwangreung & 1990 & 0 \\
\hline KFRI645 & Gurye & 2003 & 0 \\
\hline KFRI691 & Hongcheon & 2005 & 0 \\
\hline KFRI700 & Gwangreung & 2005 & 0 \\
\hline KFRI720 & Muju & 2006 & 0 \\
\hline KFRI722 & Gwangreung & 2006 & 0 \\
\hline KFRI723 & Gwangreung & 2006 & 0 \\
\hline KFRI724 & Gwangreung & 2006 & 0 \\
\hline KFRI746 & Gwangreung & 2006 & 0 \\
\hline KFRI749 & Gurye & 2006 & 0 \\
\hline
\end{tabular}

a) Korea Gyeongsangbuk-do Forest Environment Research Institute (KGFS), b) Korea Forest Research Institute (KFRI).

분석된 ITS1-5.8S rRNA-ITS2 염기서열은 미국 국립생물정 보센터 'NCBI (http://www.ncbi.nlm.nih.gov/)'의 BLAST (Basic Local Alignment Search Tool)에서 뉴클레오타이드 데 이터베이스를 이용하였다. 또한, 분석된 8종간에 염기서열 유 사성은 'ClustalW2 (http://www.ebi.ac.uk/Tools/clustalw2/)' 와 'Multalin (http://bioinfo.genotoul.fr/multalin/)'에서 검 토하였다.

\section{균주 선발}

본 연구에 사용될 우량 균주를 선발하기 위하여 18 종의 균 주를 대상으로 균주별 액체 배양 생장량 조사를 하였다. 배지 는 자체 제작한 $300 \mathrm{ml}$ 목긴 삼각플라스크에 $100 \mathrm{ml} \mathrm{PDB}$ 배지 (Difco 사)를 넣고 $1 \mathrm{~N} \mathrm{HCl}$ 또는 $1 \mathrm{~N} \mathrm{NaOH}$ 로 $\mathrm{pH} 5.0$ 으로 조절하여 $121^{\circ} \mathrm{C}$ 에서 30 분간 가압 멸균하였다. 접종원 균주는 4 주간 정치 배양된 균사체를 무균 여과하여 생체량 $3 \mathrm{~g}$ 씩을 준비된 배지에 접종하였다. 접종된 균사체는 $25^{\circ} \mathrm{C}$ 에서 40 일 동안 정치 배양하고 필터페이퍼(Whatman 사, No.5)로 감압 여과하여 $80^{\circ} \mathrm{C}$ 에서 24 시간 건조하고 건조 중량을 측정하였다.

\section{균사체 생장 기간 조사}

균사체 생장량 조사는 균주 선발 조사에서 균사 생장량이 비교적 높게 나타난 KGFS08 균주를 대상으로 액체 배양에서 생장량이 최대가 될 때까지 소요되는 기간을 측정하였다. 접 종원 균주는 4 주간 정치 배양된 균사체를 무균 여과하여 생체 량 $3 \mathrm{~g}$ 씩을 $100 \mathrm{ml} \mathrm{PDB}$ 배지에 접종하였다. 접종된 균은 $25^{\circ} \mathrm{C}$ 에서 $150 \mathrm{rpm}$ 으로 진탕 배양하면서 10 일 마다 수거하여 측정
값이 일정한 정체기에 도달하면 측정을 완료하였다. 10 일 마 다 수거된 균사체는 여과하여 건조 중량을 측정하였다.

\section{균사체 생장에 따른 배지 $\mathrm{pH}$ 변화}

균사체 생장에 따른 배지의 $\mathrm{pH}$ 변화를 조사하기 위하여 우량 균주로 선발된 KGFS08과 KFRI746을 사용하였다. 각 균 주는 4 주간 전 배양하고 $\mathrm{pH} 5.5$ 로 조절된 $100 \mathrm{ml} \mathrm{PDB}$ 배지에 균총을 $8 \mathrm{~mm}$ cork-borer로 3 개씩 접종하였다. 접종된 균은 $25^{\circ} \mathrm{C}$ 에서 51 일 동안 정치 배양하면서 3 일 마다 배지의 $\mathrm{pH}$ 를 측정하고 수거된 균사체는 동결 보존하면서 실험 완료 시에 건조 중량을 측정하였다.

\section{최적 $\mathrm{pH}$ 선발}

균사 생장을 위한 최적 $\mathrm{pH}$ 조사를 위하여 우량 균주로 선발 된 KGFS08과 KFRI746을 사용하였다. 사용된 배지는 $100 \mathrm{ml}$ $\mathrm{PDB}$ 배지를 고압 멸균하고 상온에서 $\mathrm{pH} 3.0,4.0,5.0,6.0,7.0$, $8.0,9.0$ 으로 조절하고 $0.20 \mu \mathrm{m}$ 주사기용 필터로 무균 여과하여 준비하였다. 4 주간 전 배양된 각각의 균주의 균총을 $8 \mathrm{~mm}$ cork-borer로 3 개씩 접종하였다. 접종된 균은 $25^{\circ} \mathrm{C}$ 에서 40 일 동안 정치 배양 후, 건조 중량을 측정하였다.

\section{탄소원 선발}

균사 생장에 적합한 탄소원을 선발하기 위하여 탄소원을 단일로 사용하는 Hoppkins 배지 $\left(10 \mathrm{~g}\right.$ glucose, $0.5 \mathrm{~g} \mathrm{MgSO}_{4}$, $0.1 \mathrm{~g} \mathrm{KH}_{2} \mathrm{PO}_{4}, 2 \mathrm{~g} \mathrm{KNO}_{3}$ 및 $1,000 \mathrm{ml}$ 증류수)를 응용하여 탄소원 11종(arabinose, fructose, glucose, mannose, sorbitol, 
cellobiose, lactose, maltose, sucrose, mannitol, starch; Sigma 사)을 배지에 $1 \%(\mathrm{w} / \mathrm{v})$ 으로 첨가하여 생장량을 조사하였다. 사용된 균주는 KGFS08과 KFRI746으로 4주간 전 배양된 각 균주의 균총을 $8 \mathrm{~mm}$ cork-borer로 5 개씩 $100 \mathrm{ml}$ 액체 배지에 접종하였다. 접종된 균은 $25^{\circ} \mathrm{C}$ 에서 40 일 동안 정치배양 후, 건조 중량을 측정하였다.

\section{질소원 선발}

균사 생장에 적합한 질소원을 선발하기 위하여 질소원을 단일로 사용하는 Hoppikns 배지를 응용하여 질소원 23종 (alanine, arginine, glutamic acid, glutamine, glycine, lysine, serine, threonine, valine, amino acid mixture, ammonium nitrate, ammonium phosphate, beef extract, casamino acid, casein digest, gelatin, malt extract, neopeptone, peptone, polypeptone, soytone, tryptone, yeast extract; Sigma 사)을 배지에 $0.2 \%(\mathrm{w} / \mathrm{v})$ 으로 첨가하여 생장량을 조사하였다. 사용된 균주 와 배양은 탄소원 선발 조건과 동일하게 실험하였다.

\section{배지 선발}

균사의 최적 배양을 위한 기본 배지를 선발하기 위하여 PDB 등 11종의 배지(Table 2)를 선별하여 $300 \mathrm{ml}$ 삼각플라스 크에 $\mathrm{pH} 5.0$ 으로 조절된 각각의 배지를 $100 \mathrm{ml}$ 씩 넣고 접종원 은 4주간 전 배양된 KGFS08의 균총을 $8 \mathrm{~mm}$ cork-borer로 5 개 씩 접종하였다. 접종된 균주는 $25^{\circ} \mathrm{C}$ 에서 40 일 동안 정치 배양
후, 건조 중량을 측정하였다.

\section{탄소원 농도 및 혼합 처리 조사}

탄소원 최적 농도 결정을 위하여 탄소원 선발 조사에서 우 수한 결과를 나타낸 starch, sorbitol과 우수 배지로 선발된 KTM 배지에 포함된 glucose의 첨가 농도를 조사하였다. 배지 선발 조사에서 가장 우수한 생장량을 나타낸 KTM 배지를 기 본 배지로 사용하였고 starch, sorbitol, glucose를 각각 1, 2, $3,4,5 \%$ (w/v)로 첨가하여 실험하였다. 또 탄소원의 혼합 비 율에 따른 액체 배양 생장에 미치는 영향을 조사하기 위하여 starch:sorbitol과 starch:glucose를 각각 4:1, 3:2, 1:1 비율로 혼 합하여 최종 탄소원 농도 $3 \%$ 로 첨가하여 실험하였다. 사용된 균주와 배양은 배지 선발 조건과 동일하게 실험하였다.

\section{질소원 농도 실험}

질소원 최적 농도 결정을 위하여 질소원 선발 조사에서 우 수한 결과를 나타낸 tryptone, casein digest, yeast extract의 첨가 농도를 조사하였다. 배지 선발 조사에서 가장 우수한 생 장량을 나타낸 KTM 배지를 기본 배지로 사용하였고 tryptone, casein digest, yeast extract를 각각 0.1, 0.2, 0.3, 0.4, 0.5\% $(\mathrm{w} / \mathrm{v})$ 로 첨가하여 실험하였다. 사용된 균주와 배양은 배지 선 발 조건과 동일하게 실험하였다.

\section{비타민 선발}

균사 생장에 적합한 비타민을 선발하기 위하여 탄소원·질

Table 2. Composition of basal medium used for mycelial growth of Sparassis crispa

\begin{tabular}{|c|c|c|c|c|c|c|c|c|c|c|c|}
\hline \multirow{2}{*}{ Component } & \multicolumn{11}{|c|}{ Media $^{a}$} \\
\hline & Czapek-Dox & GP & GT & Hennerberg & Hoppkins & KTM & $\mathrm{MC}$ & $\mathrm{ME}$ & Modified Lutz & $\mathrm{PD}$ & $\mathrm{YM}$ \\
\hline$\left(\mathrm{NH}_{4}\right)_{2} \mathrm{HPO}_{4}$ & & & & & & & & & 1 & & \\
\hline $\mathrm{CaCl}_{2}$ & & & & 0.1 & & & & & & & \\
\hline $\mathrm{FeSO}_{4}$ & 0.01 & & & & & & & & & & \\
\hline $\mathrm{K}_{2} \mathrm{HPO}_{4}$ & 1 & & & & & & 1 & & 1 & & \\
\hline $\mathrm{KCl}$ & 0.5 & & & & & & & & & & \\
\hline $\mathrm{KH}_{2} \mathrm{PO}_{4}$ & & & & 1 & 0.1 & 1 & 0.5 & & & & \\
\hline $\mathrm{KNO}_{3}$ & & & & 2 & 2 & & & & & & \\
\hline $\mathrm{MgSO}_{4}$ & 0.5 & & & 0.5 & 0.5 & & 0.5 & & 0.1 & & \\
\hline $\mathrm{MnSO}_{4}$ & & & & & & & & & 0.025 & & \\
\hline $\mathrm{NaNO}_{3}$ & 3 & & & 2 & & & & & & & \\
\hline $\mathrm{NH}_{4} \mathrm{NO}_{3}$ & & & & & & & & & 1 & & \\
\hline Potatoes & & & & & & & & & & 200 & \\
\hline Glucose & & 10 & 5 & 50 & 10 & 20 & 20 & & & 20 & 10 \\
\hline Starch & & & & & & 20 & & & & & \\
\hline Sucrose & 30 & & & & & & & & & & \\
\hline Peptone & & 10 & & & & 1 & 2 & 5 & & & 5 \\
\hline Tryptone & & & 10 & & & & & & & & \\
\hline Malt extract & & 15 & & & & & & 20 & 10 & & 3 \\
\hline Yeast extract & & 10 & 3 & & & 3 & 2 & & & & 3 \\
\hline
\end{tabular}

a) GP: Glucose peptone, GT: Glucose tryptone, KTM: Korea Tricholoma matsutake medium, MC: Mushroom complete, ME: Malt extract, PD: Potato dextrose, YM: Yeast extract malt extract 
소원 선발 및 최적 농도 조사를 통해 결정된 STK $(3 \%(\mathrm{w} / \mathrm{v})$ starch, $0.3 \%(\mathrm{w} / \mathrm{v})$ tryptone, $0.1 \%(\mathrm{w} / \mathrm{v}) \mathrm{KH}_{2} \mathrm{PO}_{4}$ ) 배지에 비 타민 12종(p-aminobenzoic acid, d-biotin, folic acid, niacinamide, d-pantothenic acid, pyridoxal hydrochloride, pyridoxamine dihydrochloride, pyridoxine hydrochloride, riboflavin, thiamine hydrochloride, DL-6,8-thioctic acid, vitamin $\mathrm{mix}$; Sigma 사)를 $0.1 \%(\mathrm{w} / \mathrm{v})$ 으로 첨가하여 생장량을 조사하 였다. 사용된 균주와 배양은 배지 선발 조건과 동일하게 실험 하였다.

\section{Tryptone 제조원에 따른 생장량 조사}

Tryptone의 제조원에 따른 액체 배양 생장량 조사를 위하 여 4개 회사(Difco 사, Gellix 사, MBcell 사, Sigma 사)의 tryptone을 본 연구를 통해 개발된 STK 배지에 첨가하여 생장량을 조사하였다. 사용된 균주와 배양은 배지 선발 조건과 동일하 게 실험하였다.

\section{결과 및 고찰}

\section{유전자 정보 등록}

경상북도산림환경연구원이 보유하고 있는 꽃송이버섯 균 주 KGFS01 등 8종의 ITS1-5.8S rRNA-ITS2 영역의 염기서열을 비교해보면 KGFS01은 $02,04,05,06,08$ 과 동일하고 KGFS03 은 07 과 동일하게 나타났다(data not shown). 결과적으로 8종 은 두 가지로 나누어 볼 수 있었고 ITS1-5.8S rRNA-ITS2 영역 의 459 번 염기서열이 각각 $\mathrm{G}$ 와 $\mathrm{T}$ 로 한 개의 염기서열이 다름 을 알 수 있었다. 미국 국립생물정보센터(NCBI)에 등록되어 있는 꽃송이버섯 균주들의 ITS1-5.8S rRNA-ITS2 염기서열 정 보를 분석해 보면 다른 균주에서도 459 번 염기서열이 G와 $\mathrm{T}$ 로 다르게 나타났다. 또한, 염기서열의 분석의 부분적인 오류를 감안하여 두 차례 반복 분석을 하였다. 같은 지역권 내에서 채집된 균주이지만 ITS1-5.8S rRNA-ITS2 염기서열 정보가 일 부 다른 것으로 나타났다. 하지만 ITS1-5.8S rRNA-ITS2 영역 은 종의 구분을 위하여 사용되는 부분임으로 이 영역의 분석 만으로 균주를 구별하기에는 부족한 부분이 있다. 그러나 분 석된 8종의 두 부류는 459 번 염기서열이 다르기 때문에 다른 균주라고 판단된다. 따라서 KGFS02와 KGFS07을 두 부류의 대표 균주로 선택하고 분석된 정보를 'GenBank'에 등록하였 다(accession number: GU138863, GU138864).

\section{우량 균주 선발}

경상북도산림환경연구원 균주 KGFS01 등 8종과 국립산림 과학원 균주 KFRI644 등 10종의 액체 배양 생장량을 조사한 결과, 경상북도산림환경연구원 균주에서 KGFS08, 국립산림 과학원 균주에서 KFRI746이 각각 가장 높은 값을 나타내었다 (Fig. 1). 따라서, 이 두 가지 균주를 꽃송이버섯 균사 액체 배양
특성 조사에 사용하였다.

\section{균사체 배양 기간}

꽃송이버섯 KGFS08 균주의 균사체 액체 배양 생장량은 40 일에 가장 높은 값을 나타내었고(Fig. 2), 30일에 대수기, 50 일 이후로는 정체기를 나타내었다. 이와 같은 결과는 Hiroshi [5] 의 보고와 일치하는 것으로 나타났다.

\section{배지 $\mathrm{pH}$ 변화}

균사체 액체 배양 기간에 따른 배지의 $\mathrm{pH}$ 의 변화는 Fig. 3 과 같이 나타났다. $\mathrm{pH}$ 는 51일 동안 아주 미세한 증가가 있지 만 전반적인 변화는 없는 것으로 관찰되었다. Cheong 등[3]은 $\mathrm{HB}$ 액체 배지에서 초기 $\mathrm{pH} 4.0$ 에서 배양 후, $\mathrm{pH} 3.5$ 이하가 되는 현상을 보고하였고, $\mathrm{Oh}$ [7]는 균주 3종을 대상으로 8 종의 배지에서 배양전과 후의 $\mathrm{pH}$ 변화를 측정한 결과 대부분의 배 지에서 $\mathrm{pH}$ 변화가 미비하였고 $\mathrm{MCM}$ 배지에서만 $\mathrm{pH}$ 6.0에서 $\mathrm{pH}$ 3.7로 차이가 나는 것으로 보고하였다. 이러한 결과는 배지 의 종류에 따라 다르게 나타난다는 것을 알 수 있었다. 하지만 배양 방법과 균주 종류에 따라 차이가 있을 수 있기 때문에 대량 생산 체계 구축 시에는 면밀한 검토가 필요하다고 판단 된다.

\section{최적 $\mathrm{pH}$ 선발}

균사 생장에 필수적인 $\mathrm{pH}$ 의 최적 농도를 알기 위하여 KGFS08과 KFRI746을 대상으로 $\mathrm{pH}$ 농도별 실험 결과, KGFS08은 pH 5.0, KFRI746은 pH 4.0으로 나타났다(Fig. 4). 이러한 결과는 Shim 등[12]이 $\mathrm{pH}$ 4.0, Chang and Choi [2]가 $\mathrm{pH}$ 5.0, Cheong 등[3]이 $\mathrm{pH}$ 6.0으로 본 연구와 유사하거나

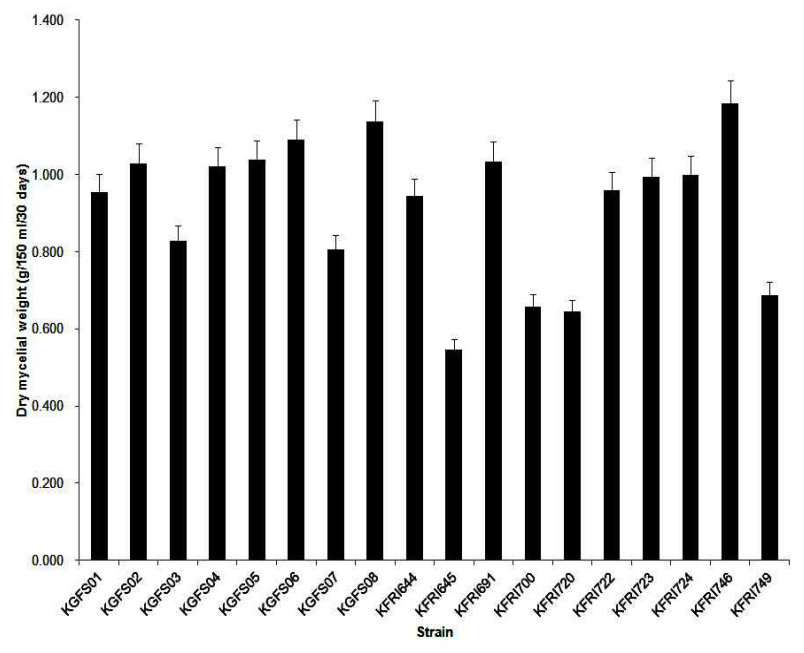

Fig. 1. Mycelial growth of Sparassis crispa strains. Stationary culture was carried out in flasks for 30 days at $25^{\circ} \mathrm{C}$ and pH 5.0 using PDB medium. Values are mean SD of triple experiments. 


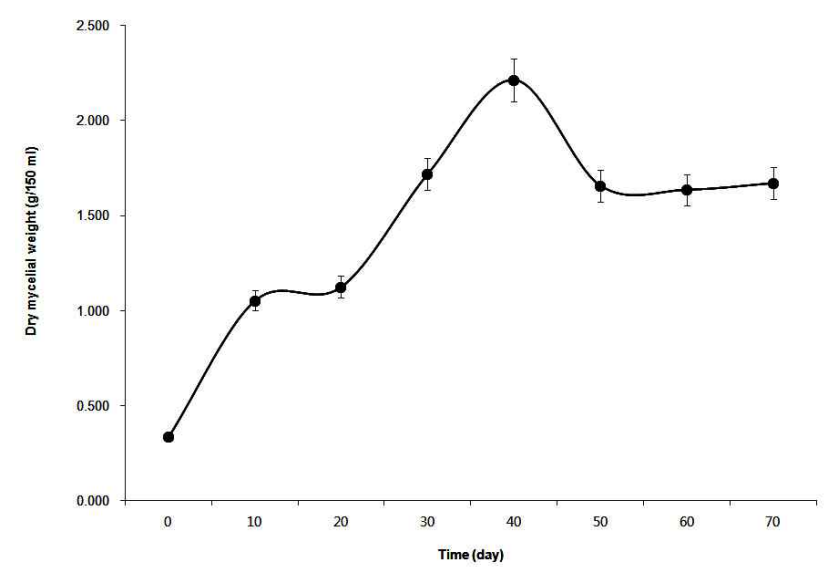

Fig. 2. Time course of mycelial growth of Sparassis crispa KGFS08. Incubation was carried out in shake flasks at $25^{\circ} \mathrm{C}$ and pH 5.0 using PDB medium. Values are mean $\mathrm{SD}$ of triple experiments.

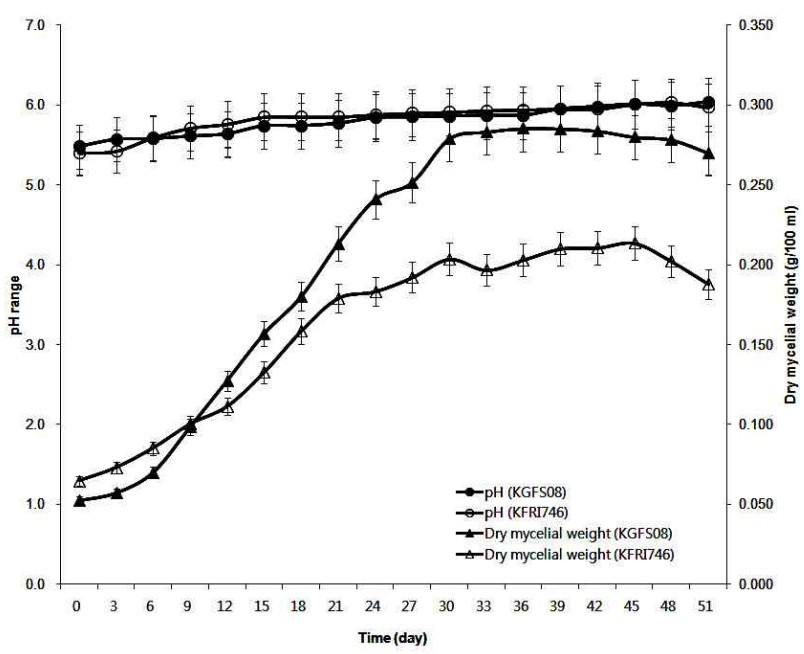

Fig. 3. The change of culture medium $\mathrm{pH}$ due to mycelial growth of Sparassis crispa in PDB medium. Incubation was carried out in shake flasks at $25^{\circ} \mathrm{C}$ using PDB medium. Values are mean SD of triple experiments.

약간의 차이가 있었다. $\mathrm{pH}$ 조사를 위하여 사용된 기본 배지의 차이가 있었고, 특히, 본 연구에서 나타난 것처럼 균주에 따라 최적 $\mathrm{pH}$ 가 다르게 나타나는 것을 알 수 있었다. 균주에 따라 최적 $\mathrm{pH}$ 가 달리 나타나는 현상은 $\mathrm{Oh}$ [7]도 유사하게 보고하였 다. 따라서, 꽃송이버섯의 균사 배양 시에는 각 균주에 따라 최적 $\mathrm{pH}$ 를 조사하여 적용하는 것이 바람직하다고 사료된다.

\section{최적 탄소원 선발}

균사의 생장에서 필수 요소인 탄소원이 그 종류에 따라 균 사 생장에 미치는 영향을 조사하기 위하여 Shim 등[12]의 기본 배지 조사에서 생장율이 가장 높은 Hoppkins 배지를 참고하 였다. 또한, Hoppkins 배지의 구성은 탄소원 glucose를 단일

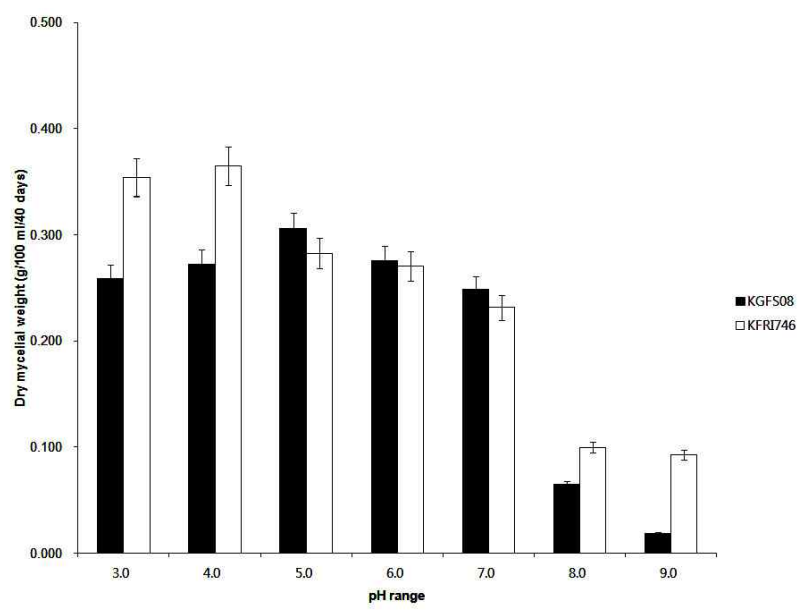

Fig. 4. Effect of various $\mathrm{pH}$ on mycelial growth of Sparassis crispa. Incubation was carried out in shake flasks for 40 days at $25^{\circ} \mathrm{C}$ using PDB medium. Values are mean SD of triple experiments.

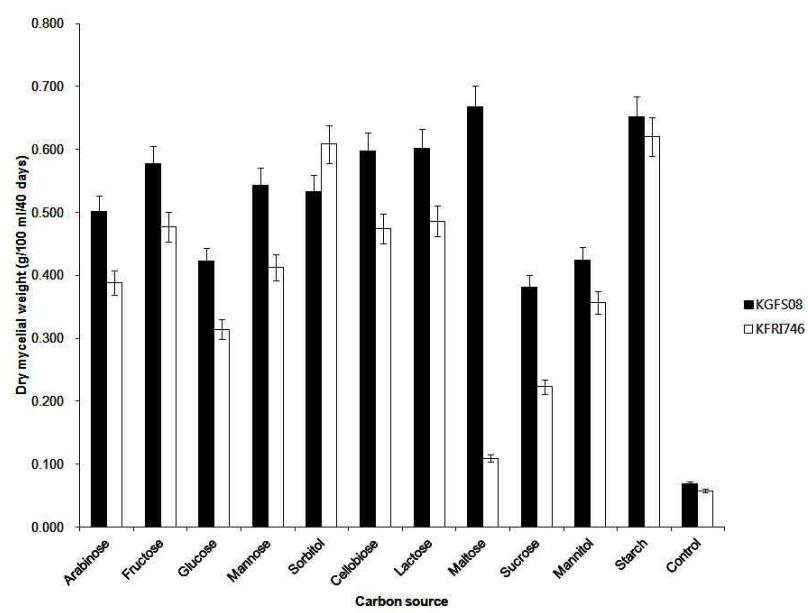

Fig. 5. Effect of various carbon sources on mycelial growth of Sparassis crispa. Incubation was carried out in shake flasks for 40 days at $25^{\circ} \mathrm{C}$ and $\mathrm{pH} 5.0$ using Hoppkins medium. Values are mean SD of triple experiments.

로 사용하고 있어 탄소원 조사에 가장 적합하다고 판단되었 다. KGFS08과 KFRI746을 대상으로 탄소원의 영향을 조사한 결과, $\mathrm{KGFS08}$ 은 starch와 maltose에서 가장 높은 값으로 나타 났고, KFRI746은 starch와 sorbitol에서 가장 높은 값을 보여주 었다(Fig. 5). 반면 일반 농가에서 쉽게 접할 수 있는 sucrose는 비교적 낮은 값을 나타내었다. 특기할 점은 KGFS08은 maltose에서 생장량이 가장 높았지만 KFRI746은 상당히 저조한 결과를 보여주었다. 실험상에 오차를 감안하여 maltose를 대 상으로 2번의 반복 실험을 하였으나 그 결과는 유사하였다 (data not shown). 이러한 결과는 Oh [7]의 보고에서도 균주에 따라 필요로 하는 탄소원이 서로 다르게 나타났으며, Shim 등[12]이 mannitol의 결과 값이 높게 나온 반면에 Cheong 등 
[3]에서 mannitol의 조건에서는 균사가 전혀 생장하지 않은 것으로 나타났다. 균사 배양에서 탄소원의 이용은 균주 특성 에 따라 다르기 때문에 사용되는 모든 균주의 적정 탄소원을 검토하여 값싼 탄소원에서 우수한 생장을 보이는 균주를 선택 함으로써 원가절감의 효과를 가져 올 수 있을 것이라고 판단 된다.

\section{최적 질소원 선발}

질소원은 세포를 구성하는 중요한 단백질, 핵산의 질소화합 물로써 균사의 생장에는 필수적이다. Hoppkins 배지는 탄소 원 선발 조사와 같은 이유로 단일 질소원을 사용하고 있어 질소원 선발 조사에 응용하였다. 최적 질소원을 선발한 결과 Fig. 6에서와 같이 KGFS08은 tryptone, casein digest가 우수하 였고, KFRI746은 yeast extract, tryptone이 우수한 것으로 나 타났다. Hiroshi [5]는 yeast extract, Cheong 등[3]은 glutamine, Shim 등 [12]은 glycine이 우수하다고 보고하였다. 하지 만 Cheong 등[3]은 glutamine이 가장 우수한 것으로 보고한 반면 Hiroshi [5]는 하위 질소원으로 보고하고 있다. 이 결과는 본 연구에서 KGFS08은 glutamine을 잘 이용하지 못하지만 KFRI746은 잘 이용하는 것으로 나타나 균주에 따라 많은 차이 가 있음을 알 수 있었다. 하지만 두 균주에서 공통적으로 yeast extract, tryptone, casein digest 등 복합 질소원이 대부분 우수 하게 나타났다. Hiroshi [5]의 보고에서도 yeast extract, soytone, meat extract 등 복합 질소원들이 우수한 질소원으로 나 타났다. 각 균주 마다 요구되는 질소원의 종류와 농도는 다를 것으로 판단되며 균사 대량 배양이 목적일 경우에는 다소 저 렴한 복합 질소원을 사용하는 것이 경제적으로 유리할 것으로 생각된다.

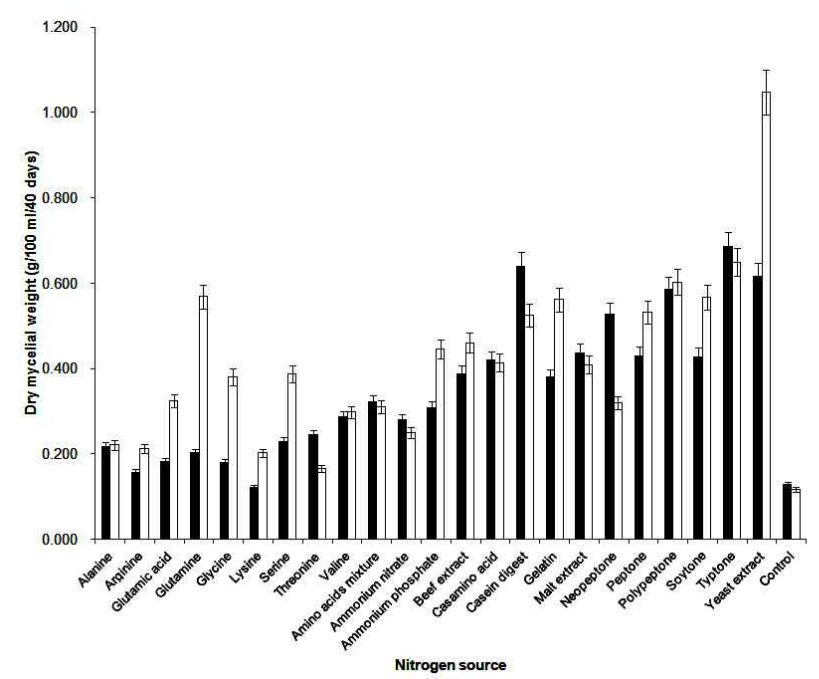

Fig. 6. Effect of various nitrogen sources on mycelial growth of Sparassis crispa. Incubation was carried out in shake flasks for 40 days at $25^{\circ} \mathrm{C}$ and $\mathrm{pH} 5.0$ using Hoppkins medium. Values are mean SD of triple experiments.

\section{최적 배지 선발}

본 연구에서 초기에 사용된 기본 배지인 Hoppkins 배지는 탄소원과 질소원을 단일로 사용하는 배지로써 탄소원과 질소 원의 단일 첨가 영향을 정확히 조사하기에 가장 적합한 것으 로 판단하였다. 하지만 균사체 배양에 사용되는 대표적인 배 지들을 검토할 필요성이 요구되어 Cheong 등[3], Shim 등[12] 의 보고에서 우수한 배지로 나타난 상위 배지 10 종을 선발하 고 본 원에서 자체 개발한 배지 1종을 대상으로 조사하였다. 결과 KTM 배지가 가장 우수한 것으로 나타났다(Fig. 7). KTM 배지는 기존에 보고된 배지들과 비교하면 탄소원을 starch와 glucose를 혼합하여 사용하는 것이 특징이고 starch $2 \%$, glucose $2 \%$ 로 탄소원의 농도가 비교적 높은 편이다. 하지만 Hennerberg 배지는 glucose의 농도가 $5 \%$ 로 상당히 높은 탄소 원 농도를 사용하지만 균사 생장량은 저조하게 나타났는데 Akihiro 등[1]의 보고에서 glucose의 농도가 $3 \%$ 에서 가장 최 적이고 $5 \%$ 이상에서 생장량이 떨어지는 결과와 유사하게 나 타났다. 탄소원 starch는 선행된 탄소원 선발 조사에서 가장 우수한 것으로 선발된 탄소원으로 KTM 배지가 우수 배지로 나타난 것은 starch의 영향인 것으로 판단된다. 또 Cheong 등 [3]과 Shim 등[12]은 PDA 배지가 비교적 우수한 배지로 보고 하였는데 본 연구에서도 PDB 배지가 평균 이상의 배지로 나 타났다. 하지만 Cheong 등[3]과 Shim 등[12]은 Mushroom complete 배지에서 균사 생장량이 저조한 것으로 나타났지만 본 연구에서는 균사 생장이 양호한 것으로 나타났다. 이 결과 도 마찬가지로 균주 간의 특성 차이도 있겠지만 실험 방법에 서 고체배지를 사용하였기 때문에 본 연구의 액체 배양 결과 와는 다소 차이가 있는 것으로 보인다. Cheong 등[3]과 Shim 등[12]은 고체배지에서 생장하는 균사의 밀도도 측정하였는데

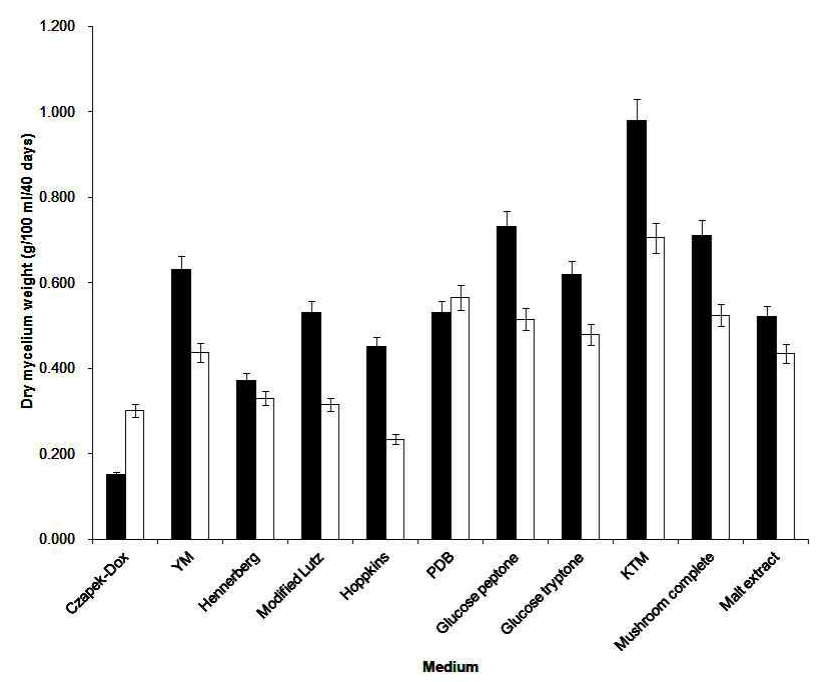

Fig. 7. Effect of various medium on mycelial growth of Sparassis crispa. Incubation was carried out in shake flasks for 40 days at $25^{\circ} \mathrm{Cand} \mathrm{pH}$ 5.0. Values are mean SD of triple experiments. 


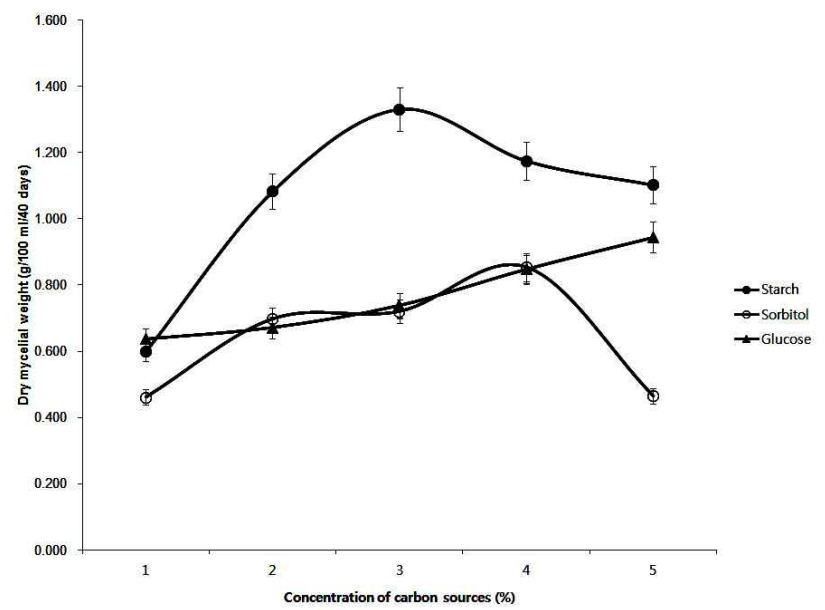

Fig. 8. Effect of carbon source (starch, sorbitol or glucose) concentration on mycelial growth of Sparassis crispa KGFS08. Incubation was carried out in shake flasks for 40 days at $25^{\circ} \mathrm{C}$ and $\mathrm{pH} 5.0$ using KTM medium. Values are mean $\mathrm{SD}$ of triple experiments.

배지마다 다양한 차이가 있는 것으로 볼 때, 액체 배양에서도 배지에 따라 균사의 생장 양상(밀도)은 매우 다를 것으로 판단 된다.

\section{탄소원 최적 농도 선발}

꽃송이버섯 균사의 액체 배양을 위한 starch, sorbitol, glucose의 최적 농도는 starch $3 \%$, sorbitol $4 \%$, glucose $5 \%$ 로 각각 나타났다(Fig. 8). 이와 같은 결과는 Hiroshi [5]의 보고에서 균사를 30 일 동안 액체 배양할 때는 starch $3 \%$ 가 가장 높은 균사 생장량을 보이는 것과 유사하다. 2종의 탄소 원 혼합 처리 조사에서는 혼합비가 3:2(starch:sorbitol)의 조 건이 가장 우수한 것으로 나타났다(Fig. 9). 혼합 처리한 조 건(3:2)과 starch $3 \%$ 를 단독 처리한 조건을 비교해 보면 혼 합 처리한 조건에서 생장량이 높게 나타났다. 하지만 그 차 이가 상당히 미비한 것으로 나타나 경제적인 면을 감안하면 starch를 $3 \%$ 로 단독 처리하는 것이 가장 적합할 것으로 판 단한다. 특기할 점은 혼합비가 4:1 (starch:sorbitol)의 조건보 다 starch $2 \%$ 를 단독으로 처리한 경우에 생장량이 더 높게 나타나는 것이다. $4: 1$ 의 혼합비율로 배지에 사용된 탄소원은 starch $2.4 \%$, sorbitol $0.6 \%$ 으로 총 $3 \%$ 이다. Starch $2 \%$ 단독 처리보다 starch가 더 포함되어 있지만 생장량은 더 저조한 것으로 보아 탄소원의 혼합이 미치는 영향에 대해서 추가적 인 연구가 필요할 것으로 판단된다.

\section{질소원 최적 농도 선발}

꽃송이버섯 균사의 액체 배양을 위한 tryptone, casein digest, yeast extract의 최적 농도는 tryptone $0.3 \%$, casein digest

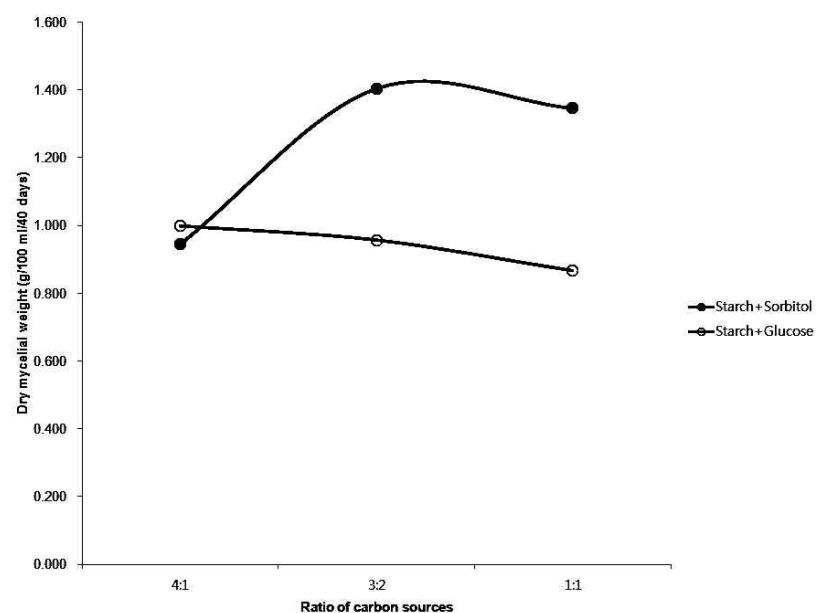

Fig. 9. Effect of starch/sorbitol or starch/glucose ratio on mycelial growth of Sparassis crispa KGFS08. Incubation was carried out in shake flasks for 40 days at $25^{\circ} \mathrm{C}$ and $\mathrm{pH}$ 5.0 using KTM medium. Values are mean SD of triple experiments.

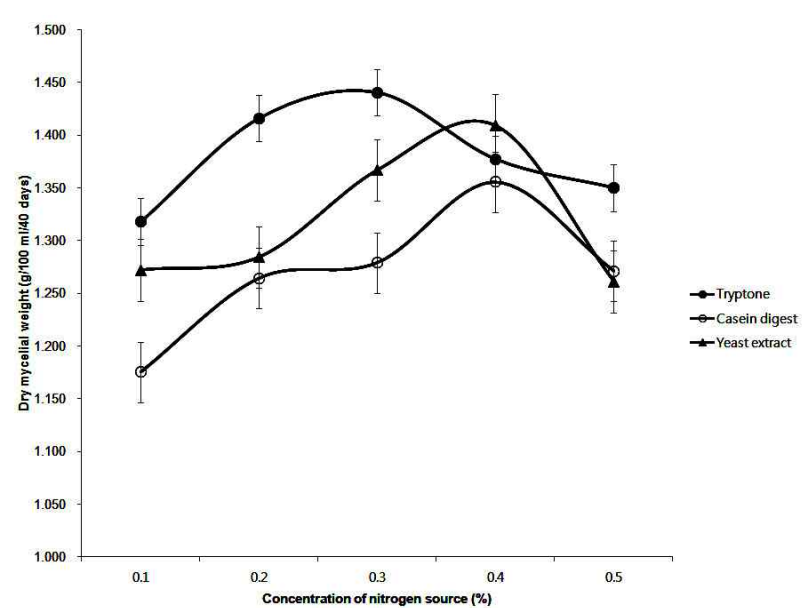

Fig. 10. Effect of nitrogen source (tryptone, casein digest or yeast extract) concentration on mycelial growth of Sparassis crispa KGFS08. Incubation was carried out in shake flasks for 40 days at $25^{\circ} \mathrm{C}$ and $\mathrm{pH} 5.0$ using KTM medium. Values are mean SD of triple experiments.

$0.4 \%$, yeast extract $0.4 \%$ 로 나타났다(Fig. 10). 각각의 질소원은 선행되었던 질소원별 액체 배양 생장량 조사와 마찬가지로 모두 우수한 생장량을 보여 주었다. 가장 우수한 결과는 tryptone $0.3 \%$ 로 나타났다.

\section{비타민 선발}

비타민은 생체촉매로써 활약하는 효소의 중요한 활성성분 으로 영양대사를 좌우하는 역할을 담당하는데 균사 생장에 미치는 영향을 조사한 결과 folic acid가 가장 우수하게 나타났 다(Fig. 11). 


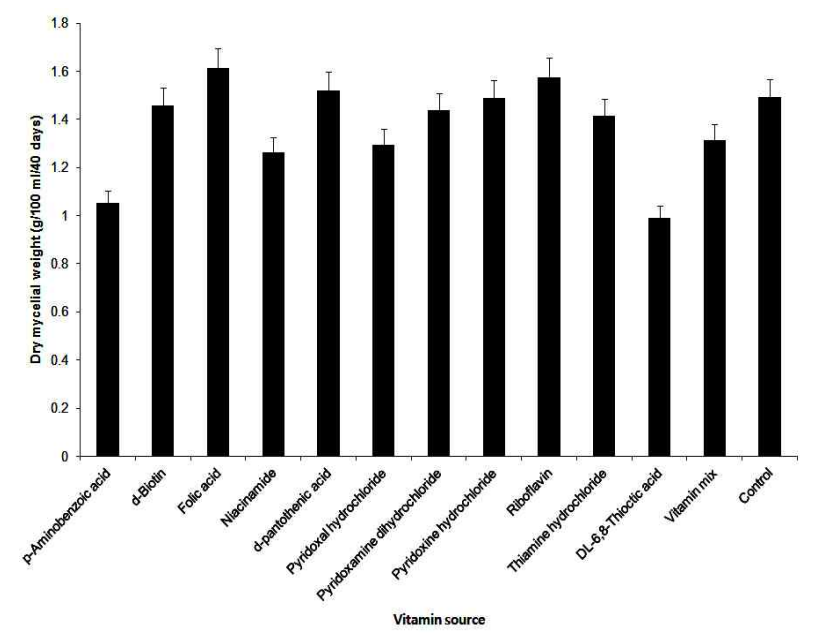

Fig. 11. Effect of vitamin sources on mycelial growth of Sparassis crispa KGFS. Incubation was carried out in shake flasks for 40 days at $25^{\circ} \mathrm{C}$ and pH 5.0 using STK medium. Values are mean $\mathrm{SD}$ of triple experiments.

\section{Tryptone 제조원 선발}

최적 질소원으로 조사된 tryptone은 $0.3 \%$ 로 배지 전체에서 는 미량이지만 균사 배양에는 상당한 영향을 미친다. 본 원의 연구 경험으로는 시약의 제조원에 따라 그 효율이 다를 것으 로 판단되어 4 개 제품을 조사한 결과 Difco 사의 tryptone이 가장 우수한 것으로 나타났다(data not shown). 저조한 결과 인 Sigma 사에 비교하면 약 $26 \%$ 효율이 차이가 나는데 이로 보아 같은 성분이라도 효율이 높은 질소원을 선택해야 할 것 으로 사료된다.

\section{감사의 글}

본 연구는 산림청 산림과학기술개발과제의 연구비 지원 사 업에 의해 수행되었습니다. 이에 감사를 드립니다.

\section{References}

1. Akihiro, K., K. Fumihisa, M. Godliving, and N. Yoshitoshi. 2006. Development of optimal culture method of Sparassis crispa mycelia and a new extraction method of antineoplastic constituent. Biochem Eng. J. 30, 109-113.

2. Chang, H. Y. and S. O. Choi. 2004. Characteristics of mycelial culture of Sparassis crispa. J. Mushroom Sci. Production. 6, 163-167.

3. Cheong, J. C., J. S. Park, I. P. Hong, S. J. Seok, C. S. Jhune, and C. J. Lee. 2008. Cultural characteristics of cauliflower mushroom, Sparassis crispa. Korean J. Mycol. 36, 16-21.

4. Harada, T., N. N. Miura, Y. Adachi, M. Nakajima, T. Yadomae, and N. Ohno. 2002. IFN- $\gamma$ induction by SCG, 1,3 $\beta$-D-glucan from Sparassis crispa, DBA/2 mice in vitro. J. Interferon Cytokine Res. 22, 1227-1239.

5. Hiroshi, Y. 2005. Nutritional requirement for the vegetative growth of Sparassis crispa Wulf:: Fr. Kanto Gakuin University, Soc. Humanity Environ. Bull. 7, 69-78.

6. Kirk, P. M., P. F. Cannon, J. C. David, and J. A. Stalpers. 2001. Ainsworth \& Bisby's Dictionary of the Fungi. Ninth edition. CABI Bioscience.

7. Oh, D. S. 2003. Studies on the optimal cultural media and conditions for mycelial growth of Sparassis crispa(Wulf.) Fr. Graduate School of Chonnam National University.

8. Oh, D. S., J. M. Park, H. Park, K. H. Ka, and W. J. Chun. 2009. Site characteristics and vegetation structure of the habitat of cauliflower mushroom (Sparassis crispa). Korean J. Mycol. 37, 33-40.

9. Ohno, N., N. N. Miura, M. Nakajima, and T. Yadomea. 2000. Antitumor 1,3-ß-glucan from cultured fruit body of Sparassis crispa. Biol. Pharm Bull. 23, 866-872.

10. Park, H., B. H. Lee, K. H. Ka, W. C. Bak, D. S. Oh, J. M. Park, and W. J. Chun. 2006. Cultivation of cauliflower mushroom (Sparassis crispa) by use of steam-treated coniferous sawdusts. Mokchae Konghak 34, 84-89.

11. Ryu, S. R., K. H. Ka, H. Park, W. C. Bak, and B. H. Lee. 2009. Cultivation characteristics of Sparassis crispa strains using sawdust medium of Larix kaempferi. Korean J. Mycol. 37, 49-54.

12. Shim, J. O., S. G. Son, S. O. Yoon, Y. S. Lee, T. S. Lee, S. S. Lee, K. D. Lee, and M. W. Lee. 1998. The optimal factors for the mycelial growth of Sparassis crispa. Korean J. Mycol. 26, 39-46.

13. Yamamoto, K., Y. Nishikawa, T. Kimura, M. Dombo, N. Matsuura, and A. Sugitachi. 2007. Antitumor activities of low molecular weight fraction derived from the cultured fruit body of Sparassis crispa in tumor-bearing mice. J. Jap. Soc. Food Sci. Technol. 54, 419-423. 
초록 : 꽃송이버섯의 균사 생장을 위한 배지 조건 최적화

김진우 ${ }^{1} \cdot$ 천우재 ${ }^{1} \cdot$ 채경희 ${ }^{1} \cdot$ 김동관 $^{2} \cdot$ 손성호 ${ }^{23}, \cdot$ 김종국 ${ }^{4} \cdot$ 임희재 $^{1}{ }^{*}$

$\left({ }^{1}\right.$ 경상북도산림환경연구원, ${ }^{2}$ (주) 비트로시스 생명공학연구소, ${ }^{3}$ 동양대학교 생명화학공학과, ${ }^{4}$ 경북대학교 생 명공학부)

본 연구에서는 균사의 액체 배양 특성 조사를 위하여 꽃송이버섯 균주 KGFS08과 KFRI746를 선발하였다. 균사 생장을 위한 우수 배지는 KTM 배지로 조사되었으며, 탄소원과 질소원은 각각 $3 \%(\mathrm{w} / \mathrm{v}) \operatorname{starch}$ 와 $0.3 \%(\mathrm{w} / \mathrm{v})$ tryptone, 비타민은 folic acid로 나타났다. 따라서 액체 배양 최적 조건은 STK 배지[3\% $(\mathrm{w} / \mathrm{v})$ starch, $0.3 \%(\mathrm{w} / \mathrm{v})$ tryptone, $0.1 \%(\mathrm{w} / \mathrm{v}) \mathrm{KH}_{2} \mathrm{PO}_{4}, 0.1 \%(\mathrm{w} / \mathrm{v})$ folic acid], $\mathrm{pH}$ 는 4.0 5.0으로 확인되었다. 